\title{
On the Identification of Trypsin-released Human Placental Cells and Their Separation Method
}

\author{
By \\ Akira Igarashi \\ From the Department of Obstetrics and Gynecology, Tohoku University \\ School of Medicine, Sendai; Director: Prof. K. Ku sh im a \\ (Received for publication, March 13, 1964)

\begin{abstract}
Many attempts have been made to identify cultured cells by many investigators. Now the ideal medium or physiological maintenance medium (Eagle), which will enable cultured cells to maintain the same characteristic properties as in vivo, has not yet been invented. The idea on which many experiments for identification are based should be reexamined. Since the cells cultured in various media are usually much altered in their morphology, stainability and many other characters, the identification always involves theoretical difficulties. Therefore, a new method for identification of cultured human placental cells should be devised.

In this experiment, the author tried to identify trypsin-released human placental cells and discussed on the separation method of the identified cells.
\end{abstract}

Recent advances in cancer research and virology seem to owe their large parts to the development of cell culture technique. Cell culture technique, moreover, offers one of the excellent tools for investigating normal cell functions. But, at present, there is no satisfactory technique to identify cultured cells in vitro.

In this experiment, the author tried to identify trypsin-released human placental cells - especially syncytial cell (S. cell) and Langhans' cell (L. cell) and to separate these identified cells, for the purpose of applying to mass isolation in the culture of S. and L. cells.

\section{MATERIALS AND METHODS}

Phase contrast microscopical observation: In this experiment, human chorionic villi, aged from 8 to 12 weeks, were used, and for trypsinization $0.25 \%$ trypsin solution was used. Phase contrast microscopical observations were made on the three kinds of objects, which were prepared as described below.

1. Trypsin-released human placental cells: human placental cells, released 
from human chorionic villi with trypsinization, were filtered through 80-mesh platinum filter and then washed with several changes of Hanks' balanced salt solution (HBSS) to rinse off trypsin. Then the cells were inoculated with medium into TD-40 type culture flask so that the cell concentration was about $2 \times 10^{4} / \mathrm{ml}$.

2. Human chorionic villi before trypsinization: human placenta removed and transferred aseptically to a sterile Petri dish, and washed with several changes of HBSS to remove it of extraneous materials. Then chorionic villi, separated from the human placenta by means of forceps, were transferred on a piece of slideglass and covered with a cover glass.

3. Human chorionic villi during trypsinization: a part of human placenta was transferred on a piece of slide-glass every ten minutes during trypsinization, and covered with a cover-glass.

Staining techniques and their objects: In this experiment, the human placenta, aged 12 weeks, was used, and for trypsinization $0.25 \%$ trypsin solution was used. Established histochemical staining procedures were used to identify trypsin-released human placental cells, for the presence of glycogen, DNA-RNA, alkaline phosphatase, acid phosphatase and acid polysaccharides content. Another staining procedures such as Giemsa stain, hematoxylin-eosin stain, and van-Gieson stain were tried also. Staining procedures described above were tried on the three kinds of subject, which were prepared as described below.

1. Human chorionic villi before trypsinization: a part of placenta was dissected into sections, after a propriate fixation and embedding.

2. Human chorionic villi during trypsinization: another part of the placenta was trypsinized for $60 \mathrm{~min}$. Then the placenta became brei-like tissue, which was placed on the 80 -mesh platinum filter. The brei-like tissue remained on the filter was then streaked on slide-glasses and fixed properly for stainings.

3. Trypsin-released human placental cells: these cells which were filtered through 80-mesh plantinum filter, were isolated by centrifugation. And the cells were streaked on the slide-glasses coated with albumin-glycerol solution, and fixed properly for stainings.

Measurement of cell diameters: To measure diameters of trypsin-released human placental cells, camera lucida was employed, and the average of the diameters of 50 cells in each type was taken.

\section{RESULTS}

\section{The results of phase contrast microscopical observation:}

1. Observation of trypsin-released human placental cells

The photomicrograph of trypsin-released human placental cells (including 
blood and fat cells) is shown in Fig. 1. These released cells are arbitrarily classified in four types (Fig. 2), according to their size. I-type cell: these giant

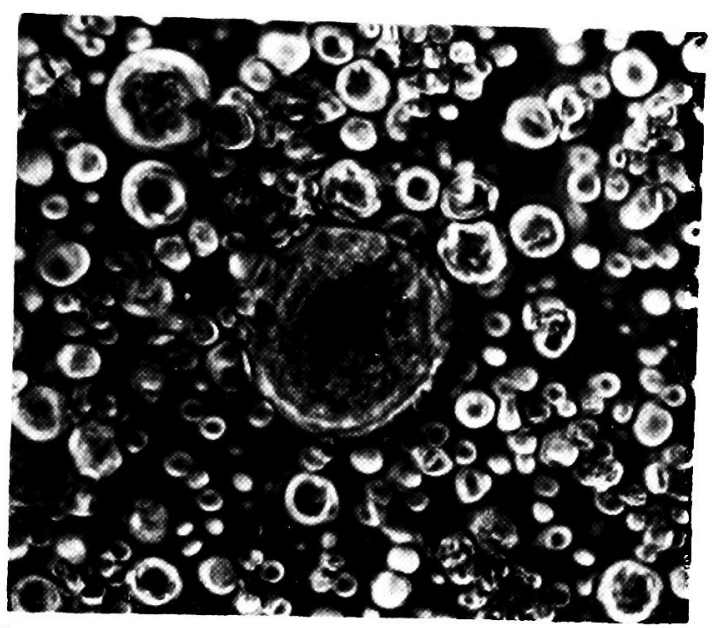

Fig. 1. Human placental cells released by trypsinization (phase contrast micrograph: $700 \times$ ).

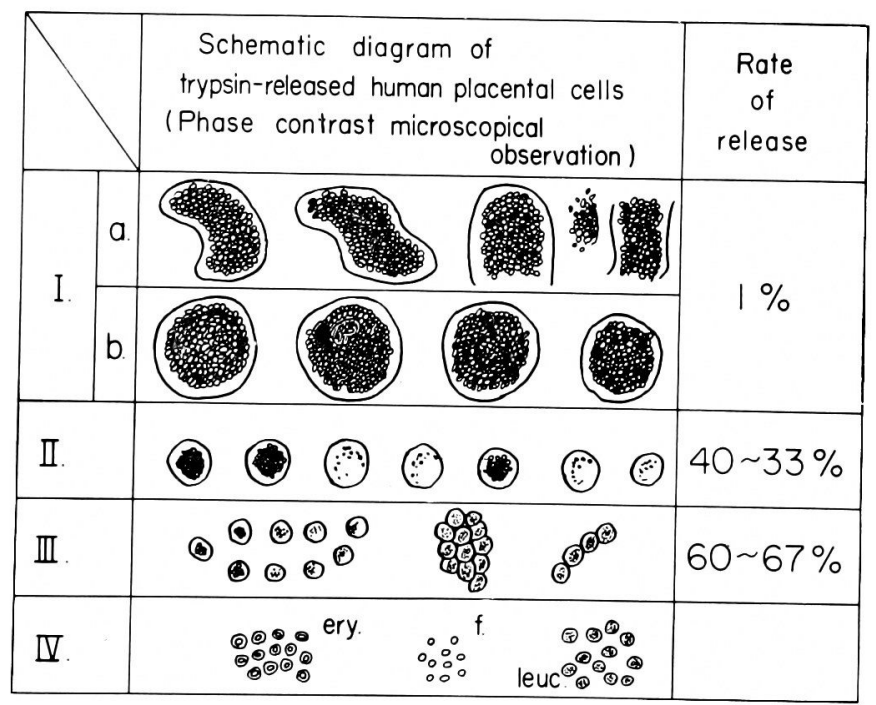

Fig. 2. Classification of trypsin-released human placental cells.

cells are classified in two subtypes, a and b. Ia-type cells were pleomorphic and could not be cultured in a culture flask. Ib-type cells were round and could be cultured in a culture flask. II-type cell: these cells are smaller than I-type 
cells but larger than III-type cells. And there were many transitional forms between II- and III-type cells in their size. III- and IV-type cell: these type cells contain all trypsin-released human placental cells, except the cells classified under I- and II-types. Observing microscopically, III-type cells could not be differentiated from leucocytes (classified under IV-type cell). But in this experiment, blood cells (ery., and leuc.) and fat cells (f.) are classified under IV-type cells. III-type cells were released mostly in an aggregated state as shown in Fig. 2. Careful observation, therefore, enable us to differentiate IIItype cells from II-type and their transitional forms. Releasing rate of these arbitrarily classified cells is demonstrated in Fig. 2, averaging the number of each type cells in 10 microscopical fields respectively. Of course, the releasing rate is presumably changeable, according to many factors. That is, the state of the placenta, the storage period of the placenta before trypsinization, all the factors that will control the trypsin activity and so on. But the order of releasing rates shown in Fig. $2(\mathrm{I}<\mathrm{II}<\mathrm{III})$ are supposed to be constant.

2. Observation of human chorionic villi before trypsinization

A part of findings is shown in Fig. 3. An external cellular layer is supposed

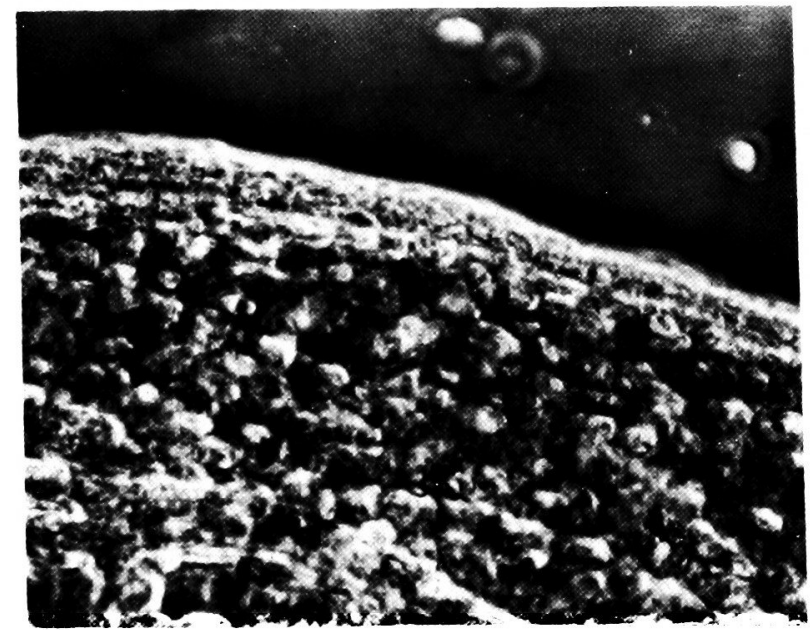

Fig. 3. Human chorionic villus (before trypsinization) (phase contrast micrograph: $700 \times$ ).

to match with a syncytial cell layer. And a continuous cellular layer beneath it is supposed to match with a L. cell layer. Small cells which fill the space beneath these two cellular layers match with interstitial cells. Many findings to be a syncytial knot, were observed at the external cellular layer. The cellular layer with fine granules above the small cells will be $\mathrm{S}$. cell layer. 
3. Observation of human chorionic villi under trypsinization

Observation was tried every ten minutes during trypsinization. Since an adequate cell number was routinely obtained after $60 \mathrm{~min}$. trypsinization, observations were tried 6 times. At the observation of these objects, attention was especially focused on the following two points; firstly, transitional shift of I-, II- and III-type cells, and secondly, the releasing state of each type cells from the original tissue. The period of trypsinization was divided into three stages as below ; 0-20 min.: 1st stage, 20-40 min.: 2nd stage, and 40-60 min.: 3rd stage. The results of observation in each stage are demonstrated in Fig. 4. At the first stage,

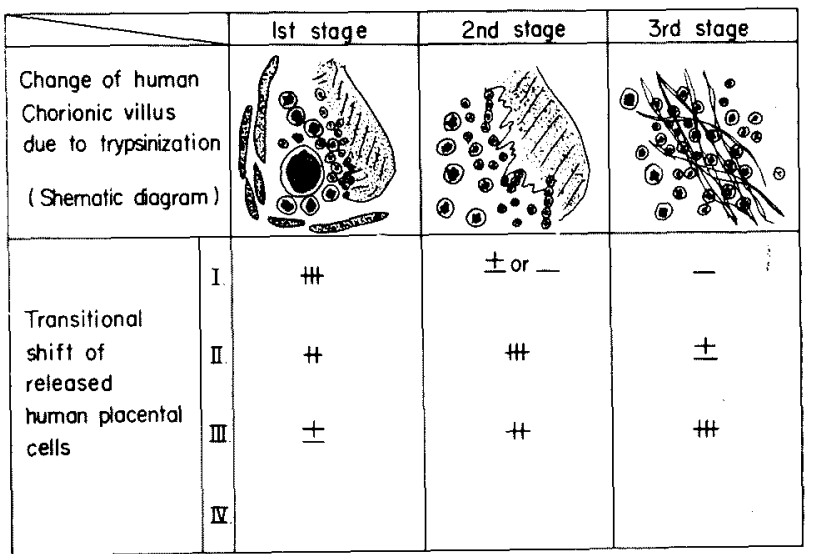

Fig. 4. Observation of human chorionic villus during trypsinization.

releasing-rate of I-type cell was prominent. The release of II-type cells was also observed, but not so prominent as that of I-type cells. Release of III-type cells could hardly be observed at this stage. Judging from the findings of phase contrast microscopy on human chorionic villi before trypsinization and from the findings above-mentioned I-type cell is supposed to be S. cell. At the second stage, the release of I-type cells could hardly be observed, while the release of II-type cells was prominent. And the release of III-type cells was not so marked.

In the third stage, the release of both I and II-type cells could hardly be observed, while most of the releasing cells were III-type cells, as shown in Fig. 5. Human chorionic villi after trypsinization consisted almost entirely of interstitial fibers with a small number of III-type cells, as shown in Fig. 6. Judging from the above findings, III-type cells are supposed to match with interstitial cells.

Findings in Preparations: On observing three kinds of preparations, attention was especially focused on the following two points; firstly, comparison of cell 


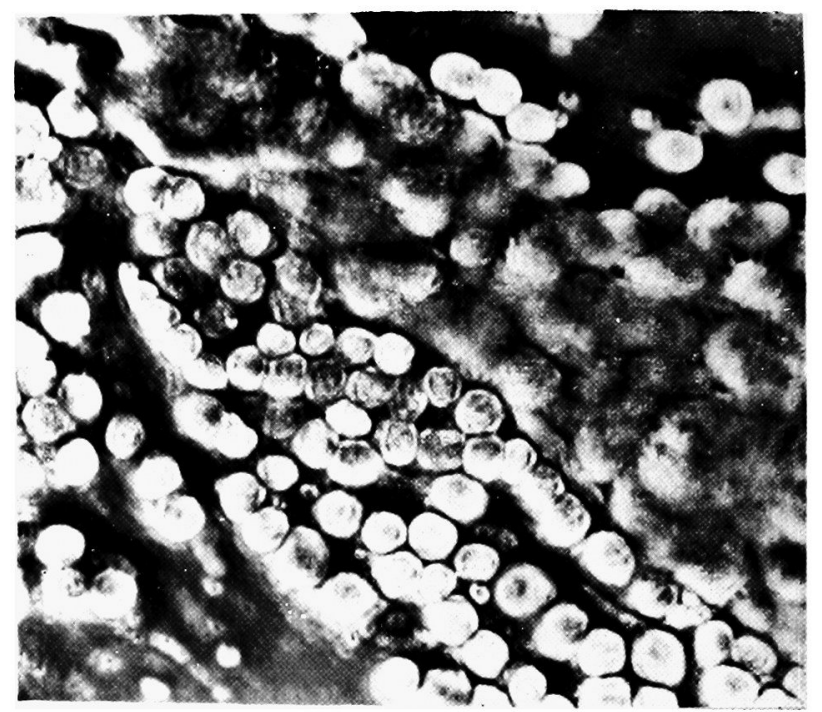

Fig. 5. Human chorionic villus during trypsinization (2nd stage) (phase contrast micrograph: $700 \times$ ).

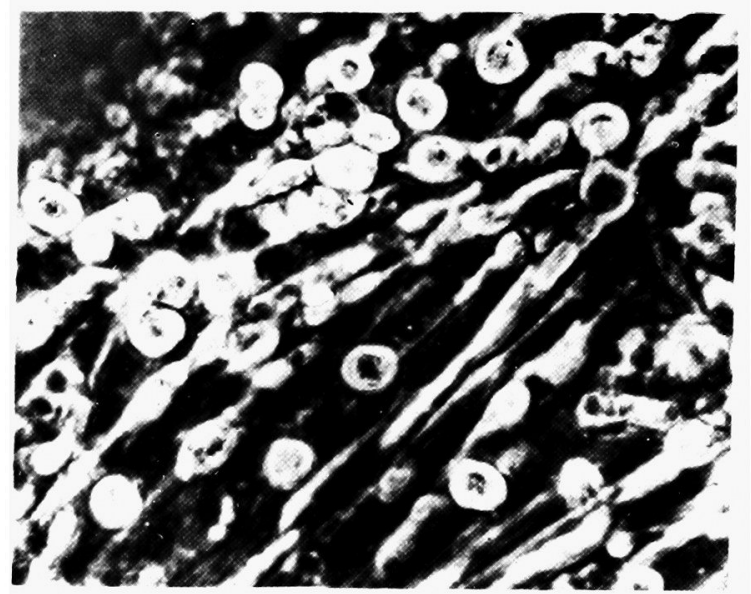

Fig. 6. Human chorionic villus after trypsinization (phase contrast micrograph: $700 \times$ ).

stainability, and secondly, the releasing states of cells from their original tissue.

1. Human chorionic villi before trypsinization

Glycogen: Cytoplasm of the cytotrophoblast of L. layer and a part of interstitial cells exhibited glycogen by PAS technique coupled with salivary digestion test. 
DNA-RNA: A small number of interstitial and L. cells were DNA-positive by the staining method with methyl-green pyronin (Taft' method). Alkaline phosphatase: With the staining method for alkaline phosphatase modified by Gomori, S. cell layer exhibited intense alkaline phosphatase activity. Acid phosphatase: With the staining method for acid phosphatase, S. cell layer had also intense acid phosphatase activity. Acid polysaccharides: For the detection of acid polysaccharides, toluidine blue stain at $\mathrm{pH} \mathrm{2.5,4.0}$ and 7.0 were performed. In these preparations, no special findings were observed, except that at $\mathrm{pH} 7.0$ a small number of interstitial cells showed metachromasia at their cytoplasm. Giemsa, van-Gieson and hematoxylin-eosin stain: The observation of these preparations offered no special findings in cell stainability.

2. Human chorionic villi during trypsinization and trypsin-released cells As many trypsin-released cells were found on preparations of human chorionic villi during trypsinization, the findings of two objects described above will be discussed together. The observation on releasing states of cells was performed, using the preparations of human chorionic villi during trypsinization.

Stained trypsin-released cells are arbitarily classified in three types according to their size, as demonstrated in Fig. 7. Giant cells were all polynuclear and

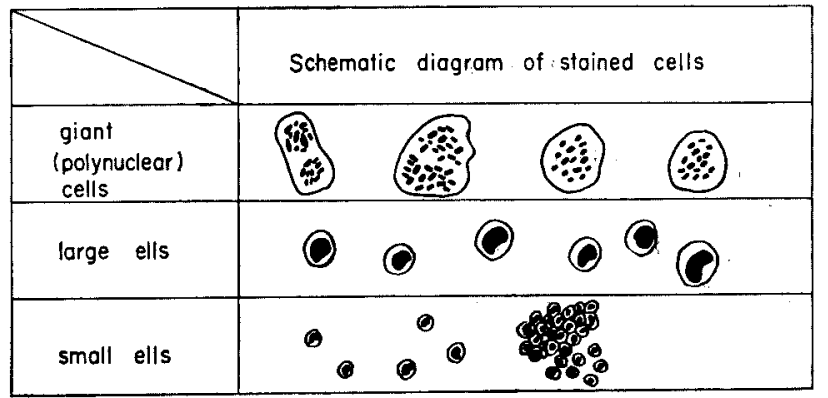

Fig. 7. Classification of stained trypsin-released human placental cells

both large and small cells were all mononuclear. Cytochemical reactions of trypsin-released cells are indicated in Table II.

Glyocgen: Cytoplasm of large cells and a small number of small cells exhibited glyeogen by PAS technique coupled with salivary digestion test. DNARNA: By the staining method of methyl-green pyronin (Taft' method), the presence of DNA was demonstrated in a part of large and small cells. Alkaline phosphatase: With the staining method for alkaline phosphatase modified by Gomori, giant (polynuclear) cells exhibited intense alkaline phosphatase activity, as shown in Fig. 9. Negative in other cells. Acid phosphatase: With staining 
TABLE I. Histochemical Reactions of Chorionic Villus (before Trypsinization)

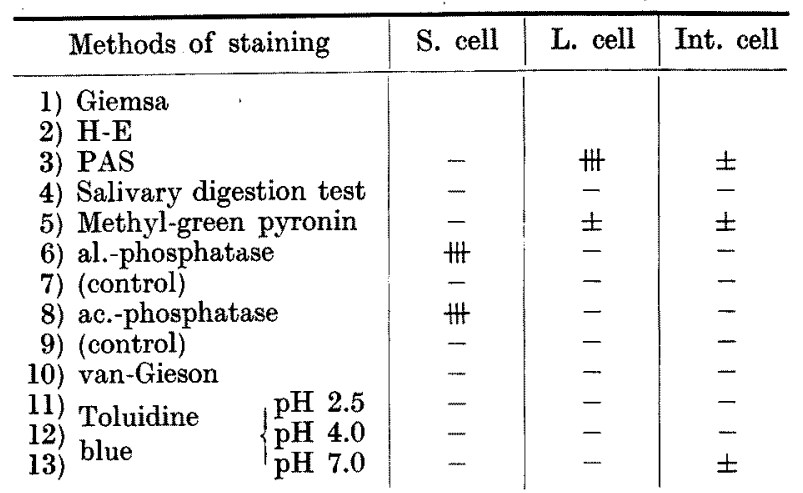

TABre II. Cytochemical Reactions of Trypsin-released Cells

\begin{tabular}{|c|c|c|c|}
\hline Methods of staining & $\begin{array}{c}\text { Giant } \\
\text { (polynucle- } \\
\text { ar) cell }\end{array}$ & Large cell & $\begin{array}{c}\text { Small } \\
\text { cell }\end{array}$ \\
\hline $\begin{array}{l}\text { 1) Giemsa } \\
\text { 2) H-E } \\
\text { 3) PAS } \\
\text { 4) Salivary digestion test } \\
\text { 5) Methyl-green pyronin } \\
\text { 6) al-phosphatase } \\
\text { 7) (control) } \\
\text { 8) ac-phosphatase } \\
\text { 9) (control) } \\
\text { 10) van-Gieson } \\
\text { 11) Toluidine } \\
\text { 12) blue } \quad \begin{cases}\mathrm{pH} & 2.5 \\
\mathrm{pH} & 4.0 \\
\mathrm{pH} & 7.0\end{cases} \end{array}$ & $\begin{array}{l}- \\
- \\
- \\
\text { H } \\
- \\
- \\
- \\
- \\
- \\
-\end{array}$ & $\begin{array}{l}\text { H } \\
- \\
\pm \\
- \\
- \\
- \\
- \\
- \\
- \\
- \\
-\end{array}$ & $\begin{array}{l} \pm \\
\overline{-} \\
\pm \\
- \\
- \\
- \\
- \\
\pm \\
\pm \\
\pm \\
\pm\end{array}$ \\
\hline
\end{tabular}

for acid phosphatase, giant (polynuclear) cells exhibited intense acid phosphatase activity.

Acid polysaccharides: For the detection of acid polysaccharides, toluidine blue stain at $\mathrm{pH} 2.5,4.0$ and 7.0 were performed. In these preparations, there are no special findings on the stainability of released cells. But the interstitial fibers partially showed reddish purple in the preparation at $\mathrm{pH} 4.0$ and 7.0.

Giemsa stain: No special findings, except that many cells which surely seemed to be leucocytes were observed. Van-Gieson stain: The observation of these preparations offered no special findings except that interstitial fibers showed a reddish appearance. Hematoxylin-eosin stain: The observation of these preparations offered the distinct concept of cell size and polynuclearity.

Releasing states of human placental cells from their original tissue is shown in 


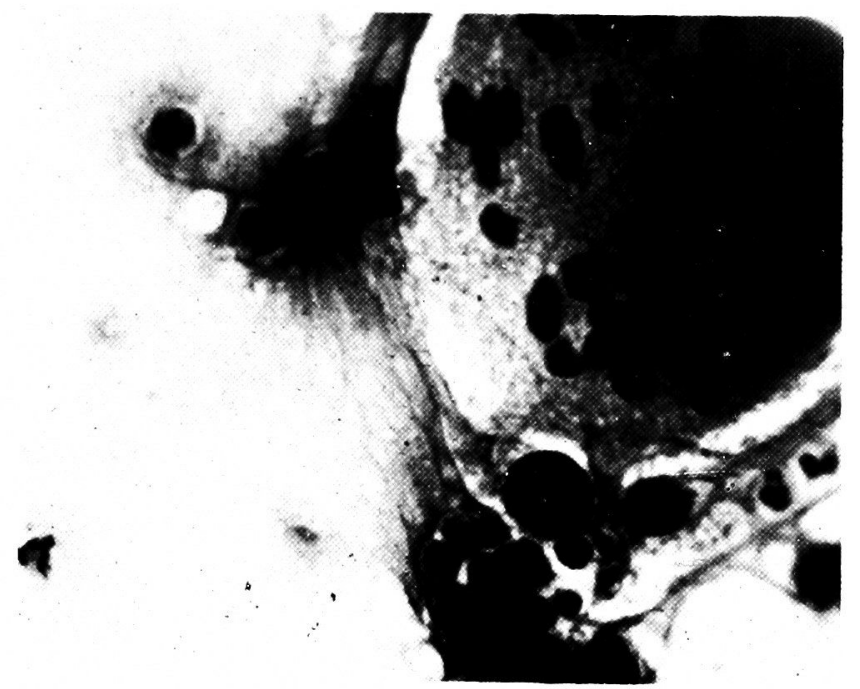

Fig. 8. Giant (polynuclear) and large cells stained with PAS. PAS-positive materials are seen in large cells $(1500 \times)$.

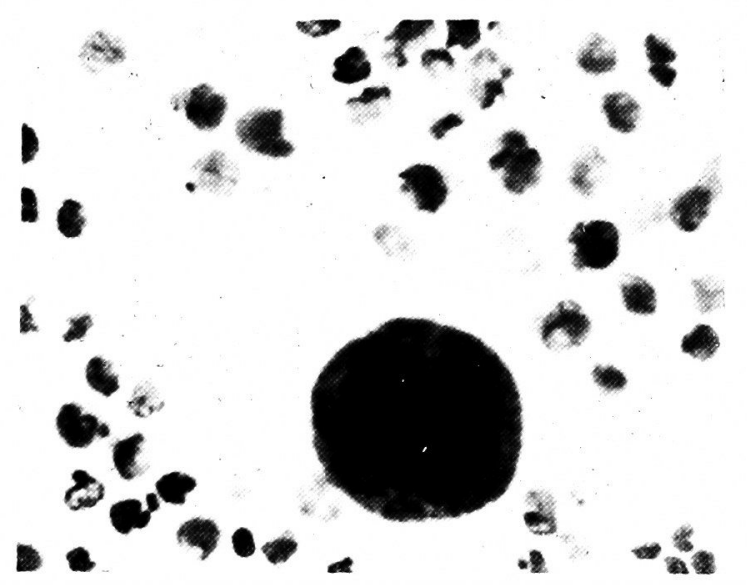

Fig. 9. Giant (polynuclear) cell, stained for acid phosphatase. Note both large and small cells did not stain $(1500 \times)$.

the schematic diagram of Fig. 10.

Diameters of trypsin-released human placental cells:

The results of measuring I-, II- and III-type cell diameters are shown in Table III. Diameters of II-type cells extended from 0.024 to $0.029 \mathrm{~mm}$. Diameters of III-type cells extended from 0.009 to $0.01 \mathrm{~mm}$. And the mean cell diameter of fifty II-type cells was $0.025 \mathrm{~mm}$ and that of fifty III-type cells was $0.01 \mathrm{~mm}$ 


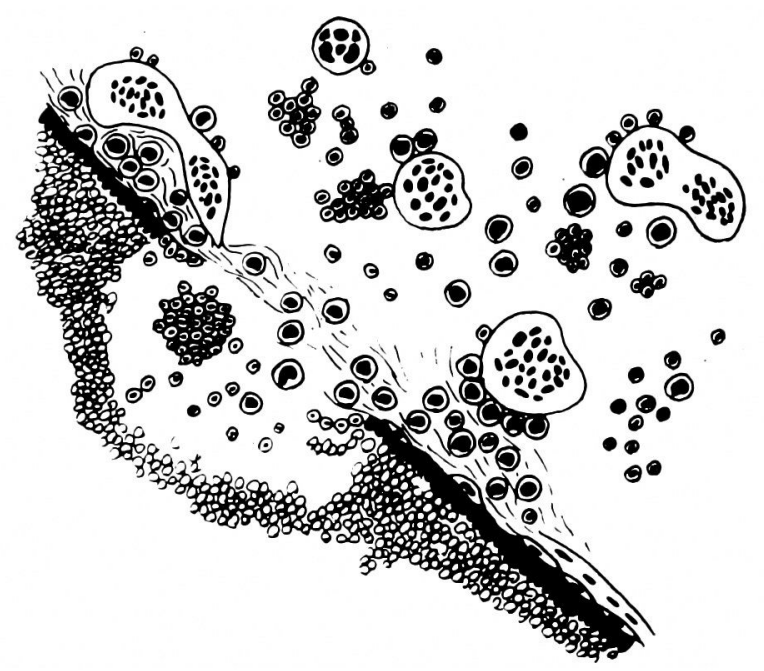

Fig. 10. Schematic diagram of histological changes of human chorionic villus due to trypsinization.

Table III. Values of Cell Diameters

\begin{tabular}{c|c}
\hline Cell types & $\begin{array}{c}\text { Cell diameter } \\
\text { (mean cell diameter) }\end{array} \quad \mathrm{mm}$ \\
\hline Ib. & $\langle 0.107-0.146<$ \\
II. & $0.024-0.027(0.025)$ \\
III. & $0.009-0.01(0.01)$
\end{tabular}

respectively. As shown in Figs 1 and 2, I-type cells have a wide variety of form and size. Accordingly, they cannot be the objects for measuring cell diameter. But the author tried to measure the diameters of some (I-b) type cells, to know the concept of cellular size of I-type cells, comparing with II- and III-type cells. Therefore, the value of I-type cell diameter is meaningless for applying to the cell separation method.

\section{DISCUSSION}

As indicated previously, since the cells cultured in various media are usualy much altered in their morphology, stainability and many other characters ${ }^{\text {7), }}$ identification always involves theoretical difficulties. Conflicting observations and conclusions on the identification of cultured human placental cells, using the index of cellular morphology, have been reported by many workers ${ }^{9-25}$. And for this reason, the cellular morphology cannot be the index for identification of cultured cells. 
Thiede $^{26)}$ and Soma ${ }^{27)}$ classified cultured human placental cells into three and four types respectively, by means of their morphology and cytochemical reactions. And they discussed on the origin of these cells, but their conclusions were not decisive.

Fujita et al. ${ }^{28)}$ emphasized the usefulness of ${ }^{3} \mathrm{H}$-thymidine for the identification of cultured cells, by using the tissue of cerebellum of kitten and chicken.

The aim of this experiment was to identify the trypsin-released human placental cells, employing phase contrast microscope and cytochemical stainings. Trypsin-released human placental cells have a wide variety in their sizes, as demonstrated in Fig. 1. It was supposed, therefore, that the detection of releasing states of these cells from their original tissue would enable us to identify these released cells, comparing with histology and cytochemical reactions of human chorionic villus. Trypsin-released cells are classified into four types according to their size, as shown in Fig. 2.

The comparison between histology of human chorionic villus and the results of phase contrast microscopical observation of human chorionic villi before and after trypsinization suggests, that I-type cells match with S. cells, most II-type cells with L. cells and most III-type cells with interstitial cells. Many transitional forms between II- and III-type cells were observed. And this seemed quite natural, for even the same type cells of human placenta may change their cellular size according to various stages of their rapid cell division. At the phase contrast microscopical observation of human chorionic villi before tryspinization, the author observed many findings that suggested the "budding of villi (Notake) 29)". It is thought, therefore, that the term of "budding (Notake)29)" should be reexamined.

As described previously, the cultured cells are usually much altered in their staining properties. Therefore, the stainability of cultured cells cannot be a marker for the identification. Makino ${ }^{30} 31$ ) reported that cultured liver cells were altered in their stainability soon after they attached to glass.

Levine $^{32)}$ investigated the effect of various manipulative procedures on labeled HeLa cells as manifested by loss of ${ }^{32} \mathrm{P}$. In his paper the following facts are reported: Repeated washings in balanced salt solutions were followed by a sudden large loss of ${ }^{32} \mathrm{P}$ during the third and subsequent washings. Of particular interest was the sudden loss of large amounts of material from the cell layer at the third and subsequent washings. And the material lost contained not only low molecular weight component, but also large molecules precipitable by trichloroacetic acid. It is apparent that repeated washings in saline solution change the permeability of the cell membrane. Washings in $0.2 \%$ trypsin solution for $15 \mathrm{~min}$. at $37^{\circ} \mathrm{C}$ and $10 \mathrm{~min}$. at $20^{\circ} \mathrm{C}$ were followed by $12.5 \%$ loss of ${ }^{32} \mathrm{P}$ during the second washings and $63.5 \%$ during the third.

Judging from the above reports, it is supposed that human placental cells 
released by trypsinization (stirring the placenta for $60 \mathrm{~min}$. at $37^{\circ} \mathrm{C}$, using $0.25 \%$ trypsin sol.) retain the sufficient intracellular materials to show, at least, the same cytochemical reactions as in section, which will be useful to identify these released cells. So that the author tried to identify these cytochemically stained trypsin-released cells by comparison with cytochemical reactions of normal human chorionic villus in section.

Mckay et $a l .{ }^{33)}$ reported the histochemistry of normal human placenta in various stages, and the cytochemical reactions of chorionic villi before trypsinization which were reported in this paper corresponds considerably to those of normal human placenta in first trimester, especially concerning to the reactions for glycogen, alkaline phosphatase and acid phosphatase.

The cytochemical reactions of trypsin-released cells for glycogen, alkaline phosphatase and acid phosphatase suggested that large cells correspond to $\mathrm{L}$. cells and giant (polynuclear) cells to $\mathrm{S}$. cells respectively. It is suspected that the phosphatase in human placental cells in vivo may be destroyed by trypsinization (stirring the placenta for $60 \mathrm{~min}$. at $37^{\circ} \mathrm{C}$, using $0.25 \%$ trypsin sol.). But, as mentioned previously, both alkaline and acid phosphatases were active in giant (polynuclear) cells and these reactions suggested the correlation between giant cells and S. cells. These facts mentioned above seem to secure the accuracy of the idea that this experiment is based on.

Observations on the releasing stages of human placental cells from their original tissue, comparing with the histology of normal human chorionic villus, suggest that giant (polynuclear) cells correspond to S. cells, large cells to L. cells and small cells to interstitial cells. Judging from the observation of preparations, the conclusion is the same as the above. Moreover, the comparison between the results of phase contrast microscopical observation and those of general microscopical observation of many preparations may permit us to conclude that: (1) I-type cells correspond to giant (polynuclear) cells and the origin of these cells is $\mathrm{S}$. cells.

(2) II-type cells correspond to large cells and the origin of most these cells is L. cells.

(3) III-type cells correspond to small cells and the origin of most these cells is interstitial cells.

Identification of cultured cells have many theoretical difficulties as indicated previously. The method that enable us to identify the cultured cells have not yet been reported. The method for identification, reported in this paper, will be applicable to identify the trypsin-released cells from their original tissue. And for this purpose, the original tissue and trypsin-released cells should be provided with the following properties, as is the case of human placenta and its trypsinreleased cells: Firstly, the original tissue should have special findings in its histology and histochemistry. Secondly, trypsin-released cells should be distin- 
guishable in their size or form with microscopical or phase contrast microscopical observation. And no one has ever tried to identify the trypsin-released cells in suspension as reported in this paper.

To separate these identified human placental cells, it seemed quite advisable to take advantage of their difference in specific gravity, but the author's experiments revealed that it was very difficult. And the difficulty seems quite natural, since specific gravities of human placental cells may presumably change according as their various stages in supposed endocrine function and rapid cell division. For example, at the phase contrast microscopical observation, different amount of intracellular granules in II-type cells has been observed.

As demonstrated in Figs. 1 and 2, I-, II- and III-type cells have considerable difference in their size, so that it was supposed that these identified human placental cells could be separated by filtrating through some platinum filter with proper pore diameter. For this purpose, the measurement of these identified cell diameters was performed, employing camera lucida. The value of each type cell diameters are shown in Table III. Platinum filters, with various kinds of pore diameter, are routinely used in cell culture technique (Table IV). And judg-

TABLE IV.

\begin{tabular}{c|c|c}
\hline $\begin{array}{c}\text { Filters } \\
(\mathrm{mesh})\end{array}$ & $\begin{array}{r}\text { Diameter of pore } \\
(\mathrm{mm})\end{array}$ & $\begin{array}{r}\text { Diameter of wire } \\
(\mathrm{mm})\end{array}$ \\
\hline 10 & 1.651 & 0.889 \\
60 & 0.25 & 0.102 \\
80 & 0.177 & 0.102 \\
100 & 0.149 & 0.102 \\
150 & 0.105 & 0.017 \\
& (allowable error $\pm 6 \%)$
\end{tabular}

ing from the reported values of trypsin-released human placental cell diameters, following filters should be employed to separate I-, II- and III-type cells; filter with $0.02 \mathrm{~mm}$ pore diameter and other filters with 80,100 and 150 meshes pore diameter.

The reported method for identification and separation of trypsin-released cells in suspension will be advisable for isolation culture of many other cells, because of following reasons: The separation of identified cells, which attached to the glass, employing such an apparatus as micromanipulator, will damage the vitality of these separated cells. Moreover it will be fast impossible to obtain these identified attached-cells in the unit of ten thousand in short time, employing such an apparatus as micromanipulator. On the contrary, the reported method will enable researchers to separate identified cells in suspension and in the unit of ten thousand, which will be suitable for their mass isolation culture. 


\section{CONCLUSIONS}

(1) The identification method of trypsin-released human placental cells was investigated, based on the results of cytochemical reactions and phase contrast microscopical observations.

(2) It is evident that these identified human placental cells will be separated, employing some platinum filters with proper pore diameters.

\section{Acknowledgment}

I should like to express my sincere thanks to Dr. I. Watanabe for his valuable cooperation.

\section{References}

1) Paul, J., Cell and Tissue Culture, Livingstone Ltd., 1960.

2) Parker, R.C., Methods of Tissue Culture, Paul B. Hoeber Inc., 1961.

3) Merchant, D.J., Kehn, KH. \& Murphy, W.H. Jr., Handbook of Cell and Organ Culture, Burgess Publishing Co., 1960.

4) Katsuta, H., Methods of Tissue Culture (Jap.), Naya Shoten, Tokyo, 1955.

5) Lison, L., Histochimie et Cytochimie Animales, Principes et Methodes, GauthiorVillars, 1953.

6) Iinuma, M., New researching methods for histology (Jap.), Ishiyakusyuppan Co. Ltd., Tokyo, 1959 .

7) Swim, H., Ann. Rev. Microbiol., 1959, 13, 141.

8) Eagle, H., Proc. of the 4th International Congress of Biochemistry, Vienna 1958, 6, 1. Pergamon Press London, 1959.

9) Zondek, B. \& Wolff, E., Zbl. Gynäk., 1924, 40, 2193.

10) Guggisberg, H. \& Neuweiler, W., ibid., 1926, 22, 1437.

11) Mayer, A. \& Heim, K., ibid. 1926, 50, 2688.

12) Heim, K., ibid. 1926, 11, 654.

13) Friedheim, E.A.H., Soc. biol. Compt. rend., 1928, 98, 123.

14) Ulesco-Stroganowa, Arch. Gynäk., 1929, 138, 52.

15) Caffier, P., Zbl. Gynäk., 1929, 38, 2410.

16) Sannicandro, G., Biol. Abstr., 1936, No. 5561.

17) Sengupta, B., Arch. exp. Zellforsch., 1936, 17, 281.

18) Maeda, S. \& Nagayama, A., Nagasaki Igakkwai Zassi (Jap.), 1934, 12, 916.

19) Nagayama, A., ibid., 1937, 15, 2665 (Jap.).

20) Kitamura, K., Mansyu Ishi (Jap.), 1941, 35, 289.

21) Gey, G.O., Science, 1938, 88, 306.

22) Jones, G.E.S. \& Gey, G.O., Bull. Johns. Hopk. Hosp., 1943, 72, 26.

23) Stewart, HL., J. Endocr., 1948, 8, 175.

24) Waltz, H.L., J. nat. Cancer Inst., 1954, 14, 1173.

25) Matsumoto, K., Nagoya Igaku (Jap.), 1959, 78, 453.

26) Thiede, A.H., Amer. J. Obstet. Gynec., 1960, 78, 636.

27) Soma, H., Ehrmann, K.L. \& Hertig, A.T., Obstet. and Gynec., 1961, 18, 704.

28) Fujita, S. \& Miyake, S., Exp. Cell Res., 1962, 28, 158.

29) Notake, Y., Atlas of Tissue Culture in Obst. \& Gynec. Report on the theme commissioned by 15th annual meeting of Japanese Obst. \& Gynec. Society, 1963, p. 12.

30) Takino, T., The proceedings of 16 th meeting of Japanese Tissue Culture Society, Tokyo (Jap.) 1963, p. 4. 31) Takino, T., Discussion at the 16th meeting of Japanese Tissue Culture Society,
Tokyo 1963.

32) Levine, S., Exp. Cell Res., 1960, 19, 220.

33) Mckay, D.G., Hertig, A.T., Adams, E.C. \& Richardson, M.V., Obstet. and Gynec.,
1958, 12, 1. 